\title{
Expenditure Pattern of Families of Sthree Shakthi Groups in Dharwad and Tumkur Districts of Karnataka, India
}

\author{
J.M. Saraswathi ${ }^{1 *}$, P.R. Sumangala ${ }^{2}$ and Nagaraj $^{3}$ \\ ${ }^{1}$ Department of Family Resource Management, Rural Home Science College, University of \\ Agricultural Sciences, Dharwad-580005, Karnataka, India \\ ${ }^{2}$ Department of Agricultural Extension, University of Agricultural Sciences, GKVK, \\ Bengaluru- 560 065, Karnataka, India
}

*Corresponding author

\section{A B S T R A C T}

\begin{tabular}{|c|}
\hline Keywords \\
\hline $\begin{array}{l}\text { Sthree Shakthi } \\
\text { Programme, } \\
\text { SHG/SHGs (Self } \\
\text { Help Group/s), } \\
\text { Expenditure Pattern }\end{array}$ \\
\hline Article Info \\
\hline $\begin{array}{l}\text { Accepted: } \\
07 \text { November } 2018 \\
\text { Available Online: } \\
10 \text { December } 2018\end{array}$ \\
\hline
\end{tabular}

The present study was conducted during 2013-14 both in Northern and Southern districts of Karnataka i.e. Dharwad \& Tumkur to observe the expenditure pattern of Sthree Shakthi Group members viz., on food, clothing and House Keeping. Three hundred Self Help Group members (120 \& 180 SHG members from Dharwad and Tumkur districts respectively)were selected and interviewed using pretested interview schedule. It was noticed that on an average, Dharwad SSG members' families spent Rs. 6,125/- to that of Rs. 5,500/- of Tumkur on cereals and millets which was found to be the major constituent of food expenditure followed by milk and milk products (Rs. 6,643/- and Rs. 5,714/- for Dharwad and Tumkur respectively). The amount spent on pulses was found to be higher among Dharwad (Rs. 4,028/-) respondent's families to that of Tumkur (Rs. 2,833/-) district. In both the selected districts the average annual amount spent on children clothing was slightly higher i.e. Rs.3,383/- by Dharwad and Rs. 3,142/- by Tumkur respondents. The average annual expenditure for celebrating festivals and functions by Dharwad (Rs.17, 092/-) SSG members' families was double than the Tumkur (Rs. 8,226/-) SSG members' families.

\section{Introduction}

The status of women in any society is an indicator of the level of its development because in the society women play critical roles in the family and outside. The concept of SHG stands to underline the principle 'for the people', 'by the people' and 'of the people'. SHG phenomenon is an important means of development offering an approach which puts people for collective action and co-ordinated management system (Fernandez, 2006). The SHG concept was originated during early 1980s and experimental attempt was made in the neighboring country i.e. Bangladesh by Dr. Mohammed Yunus, former Head of the Department of Economics, Chittagong University. National Bank for Agriculture and Rural Development (NABARD) defines Self Help Group as a group of 20 or less people from a homogeneous class who are willing to come together for addressing their common 
problems. Sthree Shakthi programme is an approach through which efforts are being made by the government with the intention to pool both human and material resources to empower women in rural areas. Sthree Shakthi programme has been implemented throughout the state during 2000-2001 by the Honorable Chief minister Sri S. M. Krishna. Sthree Shakthi Self Help Groups have formed through the Anganawadi workers in the rural areas of each taluk. About 15 to 20 lakhs women have organized under this scheme consisting of 15 to 20 women in each group and in recent years, empowerment of women has been recognized as a central issue (Bhagyalakshmi, 2004). Implementation and monitoring of the scheme is given to the Department of Women and Child Development (W\&CD). Child Development Project Officer (CDPO) is monitoring the programme by the assistance of field staffs (Anganawadi Supervisors and Anganawadi Workers). Homogeneity (members belonging to the same income or social strata) contributes much to the group success. Because, members with similar social background exhibit similar coping behavior in times of stress and will thus able to extend mutual support (Suguna, 2006). Full participation of group members and transparently in group operations (financial) and functioning (which promotes trust, mutual faith and confidence) are important contributing factors for success of SHGs (Singh and Josh, 1995). Thus, sustainable development of women's resources like their abilities, interests, skills and their potentialities are of paramount importance for the development human resources (Mehta and Sethi, 1997). In nut shell, women have a profound and pervasive effect on the health and happiness of their families, communities and local ecosystem (Gupta, 2000).Hence the present study was carried out with the following objective:
To study the Expenditure Pattern of Families of Sthree Shakthi Groups (SHGs) in Dharwad and Tumkur districts of Karnataka

\section{Materials and Methods}

The present investigation was an exploratory research design and this study was conducted purposively in Tumkur and Dharwad districts of Karnataka during 2013-14. Two districts namely, Dharwad and Tumkur were selected based on purposive sampling technique. From the selected districts, based on proportionate sampling two taluks from Dharwad districs namely Dharwad and Kalghatagi taluks were selected. Similarly, four taluks namely Pavagada, Kortagere, Chikkanayakanahalli and Tiptur taluks were selected from Tumkur district. Three villages from Dharwad and five villages from Kalghatagi taluks were selected. From Pavagada and Tiptur taluks two and four villages were selected respectively. In case of Kortagere and Chikkanayakanahalli taluks, one village from each taluk was selected (Fig. 2). Totally, 16 villages were selected purposively and thirty Sthree Shakthi Groups were selected from those sample villages. Out of thirty Sthree Shakthi Groups 300 Sthree Shakthi Self Help Group members were selected as a sample respondents. Prestructured questionnaire was the research tool used to collect the required information from the sample under the study.

\section{Results and Discussion}

Table 12 discloses the mean expenditure on food items by SSG women in the selected districts i.e. Dharwad and Tumkur. The cost of the cultivated foods used for house hold consumption was estimated based on the market value during the period of data analysis and the frequency of purchase such as daily, weekly and monthly was being converted to one unit of expenditure i,e annual expenditure on food items and the same is 
presented in the table. On an average, Dharwad SSG members' families spent Rs. 6,125/- to that of Rs. 5,500/- of Tumkur on cereals and millets which was found to be the major constituent of food expenditure followed by milk and milk products (Rs. 6,643/- and Rs. 5,714/- for Dharwad and Tumkur respectively). The amount spent on pulses was found to be higher among Dharwad (Rs. 4,028/-) respondent's families to that of Tumkur (Rs. 2,833/-) district. The next major constituents of food expenditure among Dharwad and Tumkur respondents' families were found to be vegetables with Rs. 5,442/- and Rs.4,953/-, respectively and fats and oils (Rs.4,283 for Dharwad and Rs. 3,572 for Tumkur). Apart from this considerable amount was spent on pulses i.e. Rs. 4,078 and Rs. 2,833 by Dharwad and Tumkur SSG members' families respectively followed by sugar and jaggery (Rs. 3,621 for Dharwad and Rs.3,239/- for Tumkur).

Further, The amount of Rs.2, 883/- by Dharwad and Rs. 2,683/- by Tumkur respondents was spent on purchase of nuts and oil seeds whereas an amount of Rs. 2,608/and Rs. 2,328/- from Dharwad and Tumkur respectively was spent on other food items which included bakery items, spices, tea powder, salt, ready foods etc. However, irrespective of districts the amount spent on roots and tubers was found to be less when compared to other food items i.e. Rs. 1,779/from Dharwad and Rs. 1,489/- from Tumkur district respondents' families. However, statistically there is a significant difference for each food item at 1 percent level except vegetables which was significant at 5 per cent level.

The perusal at the table 13 revealed the mean expenditure on clothing among Dharwad and Tumkur district SSG members' families. In both the selected districts the average annual amount spent on children clothing was slightly higher i.e. Rs.3,383/- by Dharwad and Rs. $3,142 /-$ by Tumkur respondents when compared to men's (for Dharwad $=$ Rs. 3,008/- and for Tumkur = Rs. 2,642/-) and women's clothing (Rs. 2,771 for Dharwad and of Rs. 2,500/- for Tumkur). The observed mean expenditure was of Rs. 3,008/- and Rs. 2,642/- for men of Dharwad and Tumkur respectively while it was Rs. 2,771/- and Rs. 2,500 for Dharwad and Tumkur respondents respectively.

Further, the data in table 14 depicts the frequency of purchase of family clothing by SSG member's families of Dharwad and Tumkur districts. With respect to Dharwad district, it was evident from the table that the majority of the children's $(92.50 \%)$ and women's (76.66\%) clothing was purchased half yearly by Dharwad samples whereas men's $(54.17 \%)$ clothing was purchased once in a year. More than 45 percent of the men purchase their cloths once in six months $(45.83 \%)$ whereas a few percentage of women's (23.34\%) and children's (7.50\%) clothing was purchased yearly.

In case of Tumkur SSG members' families cent percent of women's, more than 86 percent of children's and 71 percent of men's clothing were purchased twice in a year and the observed percentages of men and women for yearly purchase of their clothing were about 29 percent and 14 percent respectively. Thus, expenditure on clothing for women and children was not varied among Dharwad and Tumkur samples but expenditure on men's clothing varied among Tumkur respondents. They purchase more frequently (twice in a year) to that of Dharwad group (yearly purchase).

The data presented in the table 15 indicates the average expenditure of housekeeping by the related SSG members' families per year. 
Table.1 Mean expenditure on food items by the families of Sthree Shakthi Group member's of Dharwad and Tumkur districts

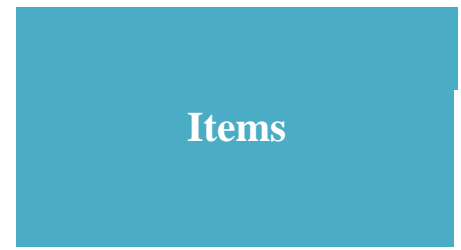

\begin{tabular}{|c|c|c|c|c|}
\hline \multicolumn{4}{|c|}{ Annual mean expenditure (in Rupees) } & \multirow{3}{*}{ Z-value } \\
\hline \multicolumn{2}{|c|}{$\begin{array}{c}\text { Dharwad } \\
n=120\end{array}$} & \multicolumn{2}{|c|}{$\begin{array}{c}\text { Tumkur } \\
\text { n=180 }\end{array}$} & \\
\hline Mean & SD & Mean & SD & \\
\hline 6,125 & 1950.27 & 5,500 & 1450.29 & $3.17 * *$ \\
\hline 4,028 & 2861.40 & 2,833 & 1980.72 & $4.27 * *$ \\
\hline 4,383 & 2258.26 & 3,486 & 1737.23 & $3.87 * *$ \\
\hline 5,442 & 1408.53 & 4,953 & 1052.66 & $2.54 *$ \\
\hline 6,643 & 2343.64 & 5,714 & 1760.39 & $3.91 * *$ \\
\hline 4,283 & 1827.35 & 3,572 & 1373.25 & $3.84 * *$ \\
\hline 2,883 & 675.92 & 2,683 & 514.86 & $2.90 * *$ \\
\hline 1,779 & 795.99 & 1,489 & 576.44 & $3.75 * *$ \\
\hline 3,621 & 1154.09 & 3,239 & 852.95 & $3.29 * *$ \\
\hline 2,608 & 775.64 & 2,328 & 493.88 & $3.82 * *$ \\
\hline
\end{tabular}

*Significant at 5 percent level

**significant at 1 percent level

Table.2 Mean expenditure on clothing by the selected respondent's families of Dharwad and Tumkur districts

\begin{tabular}{|l|c|c|c|c|c|}
\multirow{2}{*}{ Particulars } & \multicolumn{4}{|c}{ Annual mean expenditure (Rs/-) } & N=300 \\
\cline { 2 - 6 } & \multicolumn{2}{|c|}{$\begin{array}{c}\text { Dharwad } \\
\text { n=120 }\end{array}$} & \multicolumn{2}{c}{$\begin{array}{c}\text { Tumkur } \\
\text { n=180 }\end{array}$} & Z-value \\
\cline { 2 - 6 } & Mean & SD & Mean & SD & \\
\hline Women & 2,771 & 1554 & 2,500 & 1206 & $1.60 \mathrm{NS}$ \\
\hline Men & 3,008 & 2393 & 2,642 & 1654 & $1.56 \mathrm{NS}$ \\
\hline Children & 3,383 & 1471 & 3,142 & 1402 & $1.43 \mathrm{NS}$ \\
\hline
\end{tabular}

Table.14 Percentage showing the frequency of purchase of family clothing by Sthree Shakthi Group members of Dharwad and Tumkur districts

\begin{tabular}{|l|c|c|c|c|}
\multirow{2}{*}{ Particulars } & \multicolumn{2}{|c|}{$\begin{array}{c}\text { Dharwad } \\
(\mathbf{n = 1 2 0})\end{array}$} & \multicolumn{2}{c|}{$\begin{array}{c}\text { Tumkur } \\
(\mathbf{n = 1 8 0 )}\end{array}$} \\
\cline { 2 - 5 } & Half yearly & Yearly & Half yearly & Yearly \\
\hline Women & $92(76.66)$ & $28(23.34)$ & $155(86.11)$ & $25(13.89)$ \\
\hline Men & $55(45.83)$ & $65(54.17)$ & $128(71.11)$ & $52(28.89)$ \\
\hline Children & $111(92.50)$ & $09(07.50)$ & $180(100.00)$ & - \\
\hline
\end{tabular}


Table.15 Average expenditure pattern on housekeeping by Sthree Shakthi Group member's families per year

\begin{tabular}{|c|c|c|c|c|c|}
\hline \multirow{4}{*}{ Particulars } & \multicolumn{5}{|c|}{$\mathbf{N}=\mathbf{3 0 0}$} \\
\hline & \multicolumn{4}{|c|}{ Average expenditure pattern on housekeeping (in Rupees/-) } & \multirow{3}{*}{$\mathrm{Z}$ - value } \\
\hline & \multicolumn{2}{|c|}{$\begin{array}{c}\text { Dharwad } \\
(\mathbf{n}=\mathbf{1 2 0})\end{array}$} & \multicolumn{2}{|c|}{$\begin{array}{l}\text { Tumkur } \\
(n=180)\end{array}$} & \\
\hline & Mean & SD & Mean & SD & \\
\hline Children's Education & 5500 & 6863.62 & 5411 & 7046.37 & $0.10 \mathrm{NS}$ \\
\hline Health Maintenance & 3121 & 2825.65 & 2588 & 2359.36 & $1.76 \mathrm{NS}$ \\
\hline Transportation & 2704 & 3026.08 & 7093 & 4522.64 & $9.32 * *$ \\
\hline Household Bills & 2318 & 1183.14 & 2136 & 666.31 & $1.60 \mathrm{NS}$ \\
\hline Festivals and functions & 17092 & 1092.92 & 8226 & 8574.89 & $11.24 * *$ \\
\hline Fuel & 1592 & 864.77 & 1350 & 750.98 & $2.57 *$ \\
\hline
\end{tabular}

The house keeping expenditure includes expenses on children's education, health maintenance, transportation, household bills, festivals and functions and fuel. The frequency of expenditure on various housekeeping items were converted into one unit of expenditure i.e. annual expenditure of housekeeping and the same is presented in the table.

The average annual expenditure for celebrating festivals and functions by Dharwad (Rs.17,092/-) SSG members' families was double than the Tumkur (Rs. 8,226/-) SSG members' families. Second highest expenditure among Dharwad samples was found to be children's education (Rs.5,500/-) followed by health maintenance (Rs. 3,121/-) and transportation (Rs. 2,704/-) whereas Tumkur respondents expenditure was more towards transportation (mean of Rs. 7,093/-) than children's education (Rs. 5,411/-) and health maintenance (Rs. 2,588/-). Irrespective of districts, house hold bills and fuel expenses consumed were found to be nearly qual among SSG members' families i.e. Rs. 2,318/(household bills), Rs. 1,592/-(fuel) for Dharwad and Rs. 2.136/- (household bills), Rs. 1,350/(fuel) for Tumkur districts. Thus, Dharwad and
Tumkur respondents differ significantly for mean expenditure on festivals and functions $(Z$ value: 11.24$)$, transportation ( $Z$ value: 9.32$)$ at 1 percent level and for fuel ( $\mathrm{Z}$ value: 2.57$)$ at five per cent level.

\section{References}

Bhagyalakshmi, J., 2004, Women empowerment - Miles to go, Yojana a development monthly, 14(3): 24-28.

Fernandez, A.P., 2006, History and spread of Self Help Affinity Group movement in India. Discussion Paper 3, Asia and Pacific Division, Rome: IFAD.

Gupta, 2000, Strategy for empowerment of women through Self Help Groups in YSR district. Indian J. Mktg., 33(6): 12-16.

Mehta and Sethi, 1997, Success story of integrated fish farming - A self help group approach. Agric. Ext. Rev., 52(13): 33-38.

Singh and Josh, 1995, Micro credit through Self-Help Groups. J. Agric. Extn., 110(1): 24-30.

Suguna, 2006, An alternative strategy for poverty alleviation. Kisan World, 32(3): 49-50.

\section{How to cite this article:}

Saraswathi, J.M., P.R. Sumangala and Nagaraj. 2018. Expenditure Pattern of Families of Sthree Shakthi Groups in Dharwad and Tumkur Districts of Karnataka, India. Int.J.Curr.Microbiol.App.Sci. 7(12): 777-781. doi: https://doi.org/10.20546/ijcmas.2018.712.096 